\title{
Carbon Mineralization Kinetics from Legume Residues Applied to a High Altitude Acidic Soil
}

\author{
KABONEKA Salvator* ${ }^{1}$, Basil T.Iro ONG'OR ${ }^{2}$, KWIZERA Chantal ${ }^{1}$, NKURUNZIZA Menus ${ }^{3}$ and \\ KWIZERA Elie ${ }^{1}$
}

${ }^{1}$ Faculty of Agriculture and Bio Engineering, Department of Environment Sciences and Technologies, University of Burundi, B.P. 2940 Bujumbura, Burundi

${ }^{2}$ School of Engineering and Built Environment, Department of Civil and Structural Engineering, Masinde Muliro University of Science and Technology, P.O. Box 190-50100, Kakamega, Kenya

${ }^{3}$ Faculty of Sciences, Department of Mathematics, University of Burundi, B.P. 2700 Bujumbura, Burundi

\begin{abstract}
An incubation study was conducted for 56 days under room temperature in a high altitude acidic soil $(\mathrm{pH}=4.2)$ to evaluate carbon (C) mineralization from pea (Pisum sativum L.) residues and leaves from two agroforestry species (Calliandra calothyrsus Meisn and Gliricidia sepium (Jacq.) Walp. Carbon dioxide $\left(\mathrm{CO}_{2}\right)$ evolution was measured at 7, 14, 21, 28, 42 and 56 days of incubation. Carbon mineralization was best fit to a sequential decomposition model with a rapid and slow phase, each described by first-order kinetics. Percent rapid, rapid and slow fraction rate constants and half-lives were determined. At the completion of the study, percent decomposition was higher for Pisum sativum L. (77.3\%) followed by Calliandra calothyrsus Meisn (60.8 \%) and Gliricidia sepium (Jacq.) Walp (56.7\%). Similarly, higher percent rapid fractions (78\%), higher decomposition rate constants $\left(\mathrm{k}_{\mathrm{r}}\right.$ $=0.053$ day $^{-1} ; \mathrm{k}_{\mathrm{s}}=0.012$ day $\left.^{-1}\right)$ and lower half-lives $\left[\mathrm{t}_{0.5}(\mathrm{r})=13\right.$ days; $\mathrm{t}_{0.5}(\mathrm{~s})=58$ days $]$ were also observed with Pisum sativum L. residues. From the findings of this investigation, it appears that the higher lignin content of the two agroforestry species, Gliricidia sepium (Jacq.) Walp (6.33\%) and Calliandra calothyrsus Meisn (4.16\%) was the limiting factor of their decomposability, as compared to Pisum sativum L. which had zero lignin content. This study highlighted pea (Pisum sativum L.) residue as the most effective in $\mathrm{C}$ mineralization.
\end{abstract}

Key Words: Carbon dioxide, first-order kinetics, legume residues, lignin, N, C/N.

\section{INTRODUCTION}

The sustainability of crop production in Burundi is threatened by vicious cycles of declining soil fertility and increasing acidic soils in some regions. Generally, farmers are increasingly concerned about soil fragility and low organic matter in their fields. Some researchers highlighted that incorporation of plant residues may help long term soil fertility as it preserves and improves physical, chemical and biological soil properties through soil organic matter formation and maintenance [7][10][13][14]. Likewise, it was reported that the use of green manure could promote nutrient cycling and improve the synchrony of nutrient release with crop demand [3]. Nowadays, many research works are conducted to understand the pattern of legume leaf decomposition and its release of nutrients [4].

Carbon mineralization has been widely used to estimate organic material mineralization in the soil under controlled conditions [8] [11]. Carbon makes up about $45 \%$ of the elements in the dry plant biomass ${ }^{[15]}$. Hence, $\mathrm{C}$ mineralization as measured by $\mathrm{CO}_{2}$ evolution is used as a general indicator of the persistence or decomposability of organic materials applied to soil. In addition, a significant correlation between nutrient release, particularly $\mathrm{N}, \mathrm{P}$ and evolved $\mathrm{CO}_{2}$ from organic residues has been shown [8][12]. Foregoing research reported that organic materials containing more protein $(\mathrm{N})$ would decompose easily, whereas residues containing more lignin would resist microbial degradation [5]. Our hypothesis is that legume residues with higher lignin content 
would decompose slower than residues with lower lignin content. To verify this hypothesis, a study was carried out under controlled laboratory conditions using an acidic soil and two agroforestry species with high lignin content (Calliandra calothyrsus Meisn and Gliricidia sepium (Jacq.) Walp) and Pisum sativum L. with no lignin content. The aim of the study was to comparatively assess the decomposability of pea (Pisum sativum L.) residues and leaves from Calliandra calothyrsus Meisn and Gliricidia sepium (Jacq.) Walp for C mineralization.

\section{MATERIAL AND METHODS}

\subsection{Soil}

The soil used in the study was collected from the Ruzibazi Seed Center, a government farm located $50 \mathrm{~km}$ South-East of Bujumbura City, in Mukike Commune. Soil physical and chemical analyses included particle size, pH, \% C, \% N, Cation Exchangeable Capacity (CEC), exchangeable $\mathrm{Al}^{3+}$ and $\mathrm{H}^{+}$. Soil $\mathrm{pH}$ was measured using a 1:1 soil-water mixture. Organic $\mathrm{C}$ was determined by the Walkley-Black method [15]. Organic N was measured as described by Bremner and Mulvaney (1982) [2]. Selected physical and chemical properties of the soil are given in Table 1.

Table 1. Selected physico-chemical characteristics of the Ruzibazi soil

$\begin{array}{ll}\text { Parameter } & \text { Ruzibazi } \\ \mathrm{pH} & 4.2 \\ \% \mathrm{C} & 4.05 \\ \% \mathrm{~N} & 0.33 \\ \mathrm{C} / \mathrm{N} & 12.27 \\ \mathrm{CEC}\left(\mathrm{cmol}_{\mathrm{c}} / \mathrm{kg}\right) & 16.30 \\ \text { Exchangeable Al}^{3+}\left(\mathrm{cmol}_{\mathrm{c}} / \mathrm{kg}\right) & 2.33 \\ \text { Exchangeable } \mathrm{H}^{+}\left(\mathrm{cmol}_{\mathrm{c}} / \mathrm{kg}\right) & 0.37 \\ \mathrm{Clay}(\%) & 64.87 \\ \text { Silt }(\%) & 13.18 \\ \text { Sand }(\%) & 21.95\end{array}$

\subsection{Legume leaves}

Calliandra calothyrsus Meisn and Gliricidia sepium (Jacq.) Walp leaves were collected on living hedges near Bujumbura, while pea (Pisum sativum L.) residues were collected after crop harvest in Ruzibazi Seed Center. The organic materials were dried at $70^{\circ}$ $\mathrm{C}$ to a constant weight before chemical analyses were performed. Total $\mathrm{N}$ was determined by digestion with sulfuric acid $\left(\mathrm{H}_{2} \mathrm{SO}_{4}\right)$ and hydrogen peroxide $\left(\mathrm{H}_{2} \mathrm{O}_{2}\right)$ followed by steam distillation [2]. Total $\mathrm{C}$ was determined by dry combustion [15]. Total $\mathrm{P}, \mathrm{K}$, Ca and $\mathrm{Mg}$ were analyzed by ICP spectrometry after digestion of a 0.2 g-sample with $\mathrm{HNO}_{3}$ and $\mathrm{H}_{2} \mathrm{O}_{2}$ at $120^{\circ} \mathrm{C}$ for 3 hours ${ }^{[22]}$. Selected properties of the legume residues are shown in Table 2.

Table 2. Selected chemical characteristics of legume leaves

\begin{tabular}{lccc} 
Parameter & Gliricidia sepium & Calliandra calothyrsus & Pisum sativum \\
\hline$\% \mathrm{C}$ & 45.1 & 45.6 & 45.2 \\
$\% \mathrm{~N}$ & 2.93 & 3.80 & 1.37 \\
$\mathrm{C} / \mathrm{N}$ & 15.4 & 12 & 33 \\
$\% \mathrm{Lignin}$ & 6.33 & 4.16 & 0 \\
$\% \mathrm{P}$ & 0.14 & 0.25 & 0.08 \\
$\% \mathrm{~K}$ & 1.81 & 1.36 & 1.11 \\
$\% \mathrm{Ca}$ & 1.88 & 0.85 & 1.41 \\
$\% \mathrm{Mg}$ & 0.35 & 0.30 & 0.26 \\
\hline
\end{tabular}

\subsection{Incubation procedure}

Each incubation vessel $(250-\mathrm{mL})$ was fitted with 2 test tubes each containing $5 \mathrm{~mL}$ of $2 \mathrm{~N} \mathrm{KOH}_{\text {to }}$ capture evolved $\mathrm{CO}_{2}$. The laboratory incubation was conducted at room temperature $\left(27 \pm 1^{\circ} \mathrm{C}\right)$ in the soil laboratory of the Faculty of Agricultural Sciences, University of Burundi. Soil samples (50 g d.w basis) from the top-layer $(0-15 \mathrm{~cm})$ cultivated field were mixed with legume leaves 
to a field application of $1000 \mathrm{~kg} \mathrm{ha}^{-1}$., considered realistic under Burundi rural conditions. Fifty (50) mg of organic materials were homogenously mixed with soil. At this rate, 22.55, 22.80 and $22.6 \mathrm{mg}$ C were applied from Gliricidia sepium (Jacq.) Walp, Calliandra calothyrsus Meisn and Pisum sativum L., respectively. The soil was partially air dried at room temperature until it could be crashed and sieved through a $2-\mathrm{mm}$ sieve. Plant materials were cut into approximately $0.5 \mathrm{~cm}-\mathrm{long}$ sections and were incorporated in soil samples.

The mixtures soil-organic amendments were incubated under aerobic conditions under room temperature during 8 weeks. Soil moisture was set at $60 \%$ water holding capacity (WHC) and respired $\mathrm{CO}_{2}$ was regularly trapped into alkali solution and titrated with standard $\mathrm{HCl}$.

For each treatment of organic amendments, blank and control, $\mathrm{CO}_{2}$ sampling was performed at 7, 14, 21, 28, 42 and 56 days of incubation. All incubation vessels were opened and aerated for about 5 minutes at each sampling period to maintain aerobic conditions, while test tubes containing the alkali solution were simultaneously changed and titrated [20][23]. Control soils without organic amendments were set, and empty incubation vessels (blanks) were used as controls for $\mathrm{CO}_{2}$ absorbed from the atmosphere during the incubation procedure. The total $\mathrm{CO}_{2}$ collected in the dilute $\mathrm{KOH}$ solution was determined by titration to a phenolphthalein indicator endpoint with standardized $\mathrm{HCl}$ following precipitation of the carbonates with a $\mathrm{BaCl}_{2}$ solution, according to the following reactions [19]:

$\begin{array}{lll}\mathrm{CO}_{2}+2 \mathrm{KOH} & \rightarrow & \mathrm{K}_{2} \mathrm{CO}_{3}+\mathrm{H}_{2} \mathrm{O} \\ \mathrm{K}_{2} \mathrm{CO}_{3}+\mathrm{BaCl}_{2} & \rightarrow & \mathrm{BaCO}_{3}+2 \mathrm{KCl} \\ \mathrm{KOH}+\mathrm{HCl} & \rightarrow & \mathrm{KCl}+\mathrm{H}_{2} \mathrm{O}\end{array}$

\subsection{Calculations}

Carbon evolved as $\mathrm{CO}_{2}$ was estimated as follow [20]:

$$
\begin{aligned}
& \mathrm{mg} \mathrm{C} \text { as } \mathrm{CO}_{2}=(\mathrm{B}-\mathrm{V}) \times \mathrm{N} \times \mathrm{E} \\
& \text { Where: } \mathrm{B}=\mathrm{mL} \text { of standard acid for the blank; } \\
& \qquad \begin{aligned}
\mathrm{V} & =\mathrm{mL} \text { of standard acid for amended treatments; } \\
\mathrm{N} & =\text { Normality of standard acid; } \\
\mathrm{E} & =\text { Equivalent weight } \mathrm{C}(=6) .
\end{aligned}
\end{aligned}
$$

Soil basal respiration (control unamended soil) was substracted from the gross respiration to assess the net respiration associated with added organic $\mathrm{C}$ mineralization. The total respired $\mathrm{CO}_{2}-\mathrm{C}$ quantities were obtained by summing the $\mathrm{CO}_{2}-\mathrm{C}$ respired between sampling days. Percentage of decomposition was estimated by calculating the percentage of $\mathrm{C}$ added evolved as $\mathrm{CO}_{2}$ after correction for the $\mathrm{CO}_{2}$ evolved from unamended soils according to the following Equation (5):

$$
\% \mathrm{C} \text { decomposed }=[(\mathrm{X}-\mathrm{Y}) / \mathrm{Z}] \times 100
$$

\footnotetext{
Where: $\mathrm{X}=\mathrm{mg}$ of $\mathrm{C}$ evolved as $\mathrm{CO}_{2}$ from amended treatments;

$\mathrm{Y}=\mathrm{mg}$ of $\mathrm{C}$ evolved as $\mathrm{CO}_{2}$ from unamended treatments;

$\mathrm{Z}=\mathrm{mg}$ of $\mathrm{C}$ added in different leguminous leaves.
}

\subsection{Decomposition models}

Varied mathematical models have been used to describe $\mathrm{C}$ mineralization either from soil organic matter or added organic materials [9][12]. Most models follow the first-order kinetics, for which the magnitude of decomposition is assumed proportional to the quantity of mineralizable $\mathrm{C}$.

Considering the following chemical transformation: $\mathrm{C} \rightarrow \mathrm{X}$, applying the stepwise derivatives and integration will produce the model described by a differential Equation (6a).

$$
\mathrm{dC} / \mathrm{dt}=-\mathrm{k} \mathrm{C} \rightarrow \mathrm{dC} / \mathrm{C}=-\mathrm{k} \mathrm{dt}
$$

which leads to Equation (6b) after some calculations.

$$
\mathrm{C}_{\mathrm{t}}=\mathrm{C}_{\mathrm{o}} \mathrm{e}^{-\mathrm{kt}}
$$

Where: $\quad \mathrm{C}_{\mathrm{t}}=$ Carbon content at time $\mathrm{t}$ (day);

$\mathrm{C}_{\mathrm{o}}=$ initial $\mathrm{C}$ content;

$\mathrm{k}=$ first-order rate constant $\left(\right.$ day $\left.^{-1}\right)$; 


$$
\mathrm{t}=\text { time, days. }
$$

Equation (6b) describes the simple or one-component exponential model, which assumes that only one form of potentially mineralizable $\mathrm{C}$ exists and mineralizes at a rate proportional to its concentration. However, organic materials are not homogenous. They comprise organic fractions of different decomposition potentials: labile and non-labile components. The decomposition models of such organic materials follows a sequential bi-phasic model with an initial rapid phase followed by a slow decomposition phase, each described by first-order kinetics. Using various organic materials under diverse experimental conditions, such models have used by a number of investigators [6][9][12].

The sequential model assumes a complete decomposition of the rapid fraction before the slow fraction decomposition starts. The model is described by Equation (7a) for the rapid fraction and Equation (7b) for the slow fraction:

$\%$ decomposed $=100\left[\left(1-\exp \left(-\mathrm{k}_{\mathrm{r}} \mathrm{t}_{\mathrm{r}}\right)\right]\right.$

$\%$ decomposed $=(100-\%$ Rapid $)\left[1-\exp \left(-\mathrm{k}_{\mathrm{s}}\left(\mathrm{t}-\mathrm{t}_{\mathrm{r}}\right)\right)\right]$

Where: \% Rapid = amount of residue $\mathrm{C}$ in the rapid fraction; $100-\%$ Rapid $=$ amount of the residue $\mathrm{C}$ in the slow fraction; $\mathrm{k}_{\mathrm{r}}=$ rapid fraction first order rate constant; $\mathrm{k}_{\mathrm{s}}=$ slow fraction first order rate constant; $\mathrm{t}_{\mathrm{r}}(<\mathrm{t})=$ time (day) for rapid fraction complete decomposition, and

$\mathrm{t}=$ time (days).

\subsection{Statistical analyses}

The incubation study was conducted in a completely randomized design (CRD). Experimental treatments consisted of a blank, a control (soil only) and legume leaves and residues amended treatments. Each treatment was replicated three times. Decomposition of applied organic materials was described by Equation (6b) for the one-component model and Equations (7a) and (7b) for the sequential bi-phasic model.

Decomposition rate constants (k) were estimated by using the Linear Least Squares (LLS). The software used to evaluate the fitness of different models of $C$ decomposition kinetics from legume leaves and residues was JMP IN Version 3.2 [18]. Data were fitted both to the simple (one-component) and bi-phasic exponential models and for each case, decomposition rate constants ( $\mathrm{k}$ in day $^{-1}$ ) and half-lives ( $t_{0.5}$ in days) were estimated according to Equation (8).

$$
\mathrm{t}_{0.5}=0.693 / \mathrm{k}
$$

\section{RESULTS AND DISCUSSION}

\subsection{Evolved cumulative $\mathrm{CO}_{2}-\mathrm{C}$ and Percent $\mathrm{C}$ decomposition}

In application of Equation (4), Figure 1 below illustrates the quantity of evolved $\mathrm{CO}_{2}-\mathrm{C}$ for the control (soil alone), and Gliricidia sepium (Jacq.) Walp, Calliandra calothyrsus Meisn and Pisum sativum L. amended soils. The highest evolved $\mathrm{CO}_{2}$ was obtained with Pisum sativum L. residues followed by Calliandra calothyrsus Meisn and Gliricidia sepium (Jacq.) Walp leaves. As expected, the control (unamended) soils were characterized by lower quantities of evolved $\mathrm{CO}_{2}$. 
Control Soil+Gliricidia $\quad$ Soil+Calliandra Soil+Pisum

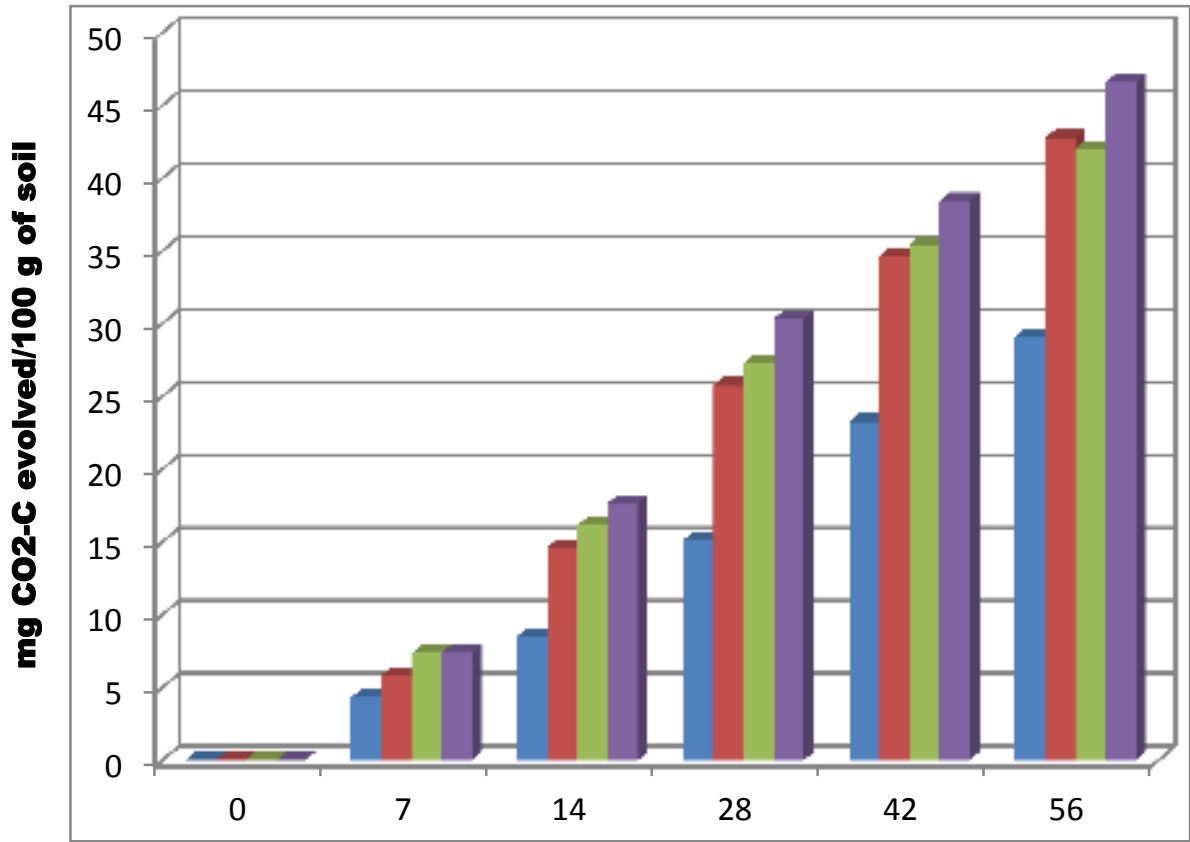

Incubation Duration (Day)

Figure 1. Cumulative $\mathrm{CO}_{2}$-C evolution from soil-applied organic amendments

At the completion of the 56-day incubation study, percent $\mathrm{C}$ decomposition from Equation (5) was as follows ( $\mathrm{p}=0.006)$ : Pisum sativum L. $(77.3 \%)>$ Calliandra calothyrsus Meisn. $(60.8 \%)>$ Gliricidia sepium (Jacq.) Walp (56.7 \%). This trend is inverse of the lignin content of the organic materials used in the present study, which was higher for Gliricidia sepium (Jacq.) Walp (6.33\%) followed by Calliandra calothyrsus Meisn (4.16\%), while that of Pisum sativum L. was nil (see Table 2 above). Considering the $\% \mathrm{C}$ mineralization shown in our data, it appears that the \% lignin content of the studied organic materials is affecting their decomposability, more than their N content $\mathrm{C} / \mathrm{N}$ ratios. Hence, our working hypothesis is verified: Gliricidia sepium (Jacq.) Walp and Calliandra calothyrsus Meisn leaves with higher lignin content decompose slower than legume residues with lower lignin content such as Pisum sativum L.

\subsection{One-component (simple) exponential model}

Most studies on $\mathrm{C}$ decomposition kinetics have used the simple (one-component) first-order kinetics as highlighted by Equation (6b). Table 3 shows the first-order kinetics parameters found in our study. First-order rate constants ranged from 0.016 to 0.036 day $^{-1}$, while half-lives ranged from 19.3 to 43.4 days. Decomposition rate constant was higher and half-life was lower with Pisum sativum $L$. residues than the other two organic materials tested.

Table 3. One-component (simple) exponential models of $\mathrm{C}$ decomposition of organic materials applied to Ruzibazi soil.

\begin{tabular}{|l|c|c|c|c|}
\hline Organic material & Decomposition model & $\mathrm{R}^{2}$ & Probability & $\mathrm{T}_{0.5}($ day $)$ \\
\hline Calliandra calothyrsus & $\mathrm{Y}=4,493-0.016 \mathrm{t}$ & 0.61 & $<0.0001$ & 43.3 \\
\hline Gliricidia sepium & $\mathrm{Y}=4,488-0.016 \mathrm{t}$ & 0.60 & $<0.0002$ & 43.3 \\
\hline Pisum sativum & $\mathrm{Y}=4,557-0.036 \mathrm{t}$ & 0.87 & $<0.0001$ & 19.3 \\
\hline
\end{tabular}

For a comparison purpose, Table 4 indicates organic material decomposition parameters (rate constant $-\mathrm{k}-$ and half-life $-\mathrm{t}_{0.5^{-}}$) reported in similar studies conducted under various conditions, in Africa and elsewhere. 
International Journal of Advances in Scientific Research and Engineering (ijasre), Vol 5 (4), April-2019

Table 4. Effect of organic material type and geographic (climate) location on decomposition parameters.

Organic material

Rye straw (Nigeria)

Rye straw (England)

Wheat straw (Canada)

Buried wheat straw (Burundi)

Surface-applied wheat straw (Burundi)

Lignin

Natural grass

$\begin{array}{lc}\underline{\mathrm{k}\left(\text { day }^{-1}\right)} & \underline{\mathrm{t}_{0.5}} \underline{\text { (day })} \\ 0.04 & 17.33 \\ 0.01 & 69.30 \\ 0.03 & 23.10 \\ 0.0134 & 57.72 \\ 0.0062 & 111.77 \\ 0.003 & 231 \\ 0.006 & 115.50\end{array}$

$\underline{\text { References }}$

Paul \& Clark (1988) [16]

Paul \& Clark (1988)

Paul \& Clark (1988)

Bicereza (2001) [1]

Bicereza (2001)

Paul \& Clark (1988)

Paul \& Clark (1988)

\subsection{Biphasic (two-component) exponential model}

Simple (one-component) first-order equations have been found not to accurately describe substrate $\mathrm{C}$ mineralization from initiation to completion, because of the heterogeneity of organic substrates under decomposition [17]. In fact, it must be stressed out that the main components of organic materials include easily oxidizable soluble organic $\mathrm{C}$ (sugars, starch, amino acids); proteins, hemicellulose, cellulose and lignin, which, in our understanding, should not metabolize (decompose) in a similar way.

In a study on kinetics of varied added organic matter decomposition in a sandy soil, the superiority of the double exponential model over a simple (one-component) model was observed ${ }^{[21]}$. Parallel to fitting our data to a simple (one-component) exponential model, in application of Equations (7a) and (7b), we also evaluated the double (two-component) exponential C decomposition model. Parameters generated by such model are shown in Table 5 below.

Table 5. Biphasic (two-component) exponential models of $\mathrm{C}$ decomposition of organic materials applied to Ruzibazi soil.

\begin{tabular}{|l|r|r|r|r|r|}
\hline Organic material & \multicolumn{1}{|c|}{$\mathrm{k}_{\mathrm{r}}$} & \multicolumn{1}{c|}{$\mathrm{k}_{\mathrm{s}}$} & $\mathrm{t}_{0.5}(\mathrm{r})$ & \multicolumn{1}{c|}{$\mathrm{t}_{0.5}(\mathrm{~s})$} & \% Rapid \\
\hline Calliandra calothyrsus & 0.029 & 0.002 & 24 & 347 & 55 \\
\hline Gliricidia sepium & 0.029 & 0.002 & 24 & 347 & 55 \\
\hline Pisum sativum & 0.053 & 0.012 & 13 & 58 & 78 \\
\hline
\end{tabular}

Compared to the two other organic materials under investigation, the double (two-component) exponential model indicates that Pisum sativum L. residues are characterized by a higher proportion of rapid fraction (78 \%) and subsequently higher decomposition rate constant $\left(\mathrm{k}_{\mathrm{r}}=0.053\right.$ day $\left.^{-1}\right)$ and lower half-lives $\left[\mathrm{t}_{0.5}(\mathrm{r})=13\right.$ days and $\mathrm{t}_{0.5}(\mathrm{~s})=58$ days]. Despite its lower $\mathrm{N}$ content (1.37\%) and high C/N (33), pea (Pisum sativum L.) residues decomposed faster than Calliandra calothyrsus Meisn (\% N $=3.80 ; \mathrm{C} / \mathrm{N}=12)$ and Gliricidia sepium (Jacq.) Walp $(\% \mathrm{~N}=2.93 ; \mathrm{C} / \mathrm{N}=15.4)$, which were characterized by higher $\mathrm{N}$ contents and lower $\mathrm{C} / \mathrm{N}$ ratios. The lignin content is apparently the controlling factor of the decomposability of the soil applied organic materials.

\section{CONCLUSION}

Organic $\mathrm{C}$ mineralization as measured by $\mathrm{CO}_{2}$ evolution is used as an indicator of the persistence or decomposability of organic materials applied to soil. This methodology was used to compare the decomposability of leaves from two agroforestry legume species (Calliandra calothyrsus Meisn and Gliricidia sepium (Jacq.) Walp) and pea (Pisum sativum L.) residues collected after crop harvest. At the completion of the incubation study, percent $\mathrm{C}$ mineralization followed the order: Pisum sativum L. (77.3\%) > Calliandra calothyrsus Meisn $(60.8 \%)>$ Gliricidia sepium (Jacq.) Walp (56.7 \%). This trend does neither follow the N content nor the $\mathrm{C} / \mathrm{N}$ ratios of the organic materials tested. Instead, this study shows that lignin content is the controlling factor of their decomposability. As a matter of fact, lignin content followed an opposite trend to percent C decomposition: Pisum sativum L. (0 $\%)<$ Calliandra calothyrsus Meisn $(4.16 \%)<$ Gliricidia sepium (Jacq.) Walp (6.33\%). Carbon mineralization data were fitted to simple (one-component) and biphasic (two-component) exponential models. The latter model was considered biochemically more realistic, because organic materials are composed of various biochemical structures with presumably different decomposability potentials. Pisum sativum L. showed higher percent rapid fractions $(78 \%)$, higher decomposition rate constants $\left(\mathrm{k}_{\mathrm{r}}=0.053\right.$ day ${ }^{-1}$; $\mathrm{k}_{\mathrm{s}}=0.012$ day $\left.^{-1}\right)$ and lower half-lives $\left[\mathrm{t}_{0.5}(\mathrm{r})=13\right.$ days; $\mathrm{t}_{0.5}(\mathrm{~s})=58$ days $]$ than the two agroforestry legume species $($ Calliandra calothyrsus Meisn and Gliricidia sepium (Jacq.) Walp). The higher lignin content of the latter species is a limiting factor of their decomposability. The results revealed pea (Pisum sativum L.) residues as the most efficient in carbon mineralization. 


\section{REFERENCES}

[1] Bicereza, D. 2001. Décomposition de la paille de blé dans un sol d'altitude du Burundi en conditions de laboratoire: effet du mode d'application. Mémoire d'Ingénieur Agronome. Université du Burundi.

[2] Bremner, J.M. and C.S. Mulvaney. 1982. Nitrogen-Total, pp. 595-624. In: A. L. Page, R.H. Miller, and D.R. Keeney (eds.), Methods of Soil Analysis. Part 2. 2nd ed. Agronomy 9. American Society of Agronomy, Madison, WI.

[3] Cob, J.G., E. Burrios, D. C. L. Kass and R. J. Thomas. 2002. Decomposition and nutrient release by green manures in tropical hillside agro-ccosystem. Plant Soil 23:331-342.

[4] Davidson E.A and I.A. Janssens . 2006. Temperature sensitivity of soil carbon decomposition and feedbacks to climate change. Journal of Nature 440: 165-173

[5] Delve, R.J. 2004. Combatting nutrient depletion in East Africa - the work on the SWNM program. Pge 127-136. In A. Bationo. Managing Nutrient Cycles to sustain Soil Fertility in Sub-Saharan Africa. AfNet-CIAT. 608 p. Nairobi.

[6] Franzluebbers, K., R.W. Weaver, A.S.R. Juo, and A.J. Franzluebbers. 1994. Carbon and nitrogen mineralization from cowpea plant part decomposition in moist and in repeatedly dried and wetted soils. Soil Biol. Biochem. 26: 1379-1387.

[7] Goh K.M, D.R. Pearson and M.J. Daly. 2001. Effect of apple orchard production systems on some important soil physical, chemical and biological quality parameters. Biology Agriculture and Horticulture 18:269-292.

[8] Gilmour, J.T., Clark, M.D. and G.C. Sigua. 1985. Estimating net nitrogen mineralization from carbon dioxide evolution. Soil Sci. Soc. Am. J. 49: 1398-1402.

[9] Gilmour, J.T., M.D. Clark and S.M. Daniel. 1996. Predicting long-term decomposition of biosolids with a seven day test. J. Environ. Qual. 35: 766-770.

[10] Haynes RJ. 1980. Influence of soil management practice on the orchard agro-ecosystem. Agro-Ecosystems 6: 3-32

[11] Janzen, H.H. and R.M.N. Kucey. 1988. C, N, S mineralization of crop residues as influenced by crop species and nutrient regime. Plant Soil 106: 35-41.

[12] Kaboneka, S., W.E. Sabbe and A. Mauromoustakos. 1997. Carbon decomposition kinetics and N mineralization from corn, soybean and wheat residues. Commun. Soil Sci. Plant Anal. 28: 1359-1373.

[13] Kumar K. and K.M. Goh. 2000. Crop residues and management practices: effects on soil quality, soil nitrogen dynamics, crop yield, and nitrogen recovery. Advance Agronomy 68: 197-319.

[14] Kumar K., K.M. Goh, W.R. Scott WR and C.M. Frampton. 2001. Effects of N-15-labelled crop residues and management practices on subsequent winter wheat yields, nitrogen benefits and recovery under field conditions. Journal of Agricultural Science 136: 35-53.

[15] Nelson, D.W. and L.E. Sommers. 1982. Total carbon, organic carbon, organic matter, pp. 643-698. In: A.L. Page, R.H. Miller, and D.R. Keeney (eds.), Methods of Soil Analysis. Part 2. 2nd ed. Agronomy 9. American Society of Agronomy, Madison, WI.

[16] Paul, E.A. and F.E. Clark. 1988. Soil Microbiology and Biochemistry. Academic Press. San Diego.

[17] Reddy, K.R., R. Khaled and M.R. Overcash. 1980. Carbon transformations in the land areas receiving organic wastes in relation to nonpoint source pollution: a conceptual model. J. Environ. Qual. 9: 434-442.

[18] SAS, 1996. A guide to statistical and data analysis using JMP and JMP IN software. Statistical Analysis System Institute, Inc., Cary, NC.

[19] Stevenson, F.J. 1986. Cycles of Soil. Carbon, Nitrogen, Phosphorus, Sulfur, Micronutrients. John Wiley \& Sons, New York, NY.

[20] Stotzky, G. 1965. Microbial respiration. p. 1550-1569. In Black, C.A et al., (ed.). Methods of soil analysis. Part 2. Agronomy 9. American Society of Agronomy, Madison, WI.

[21] Thuriès, L., M. Pansu, C. Feller, P. Herrmann and J.C. Rémy. 2001. Kinetics of added organic matter decomposition in a Mediterranean sandy soil. Soil Biology \& Biochemistry 11: 997-1010.

[22] Zarcinas, B.A., B. Cartwright and L.R. Spouncer. 1987. Nitric acid digestion and multi-element analysis of plant material by inductively coupled plasma spectrometry. Commun. Soil Sci. Plant Anal. 180: 131-146.

[23] Zibilske, L.M. 1994. Carbon decomposition. In Weaver et al. (ed.). Methods of soil analysis. Part 2. Microbial and biochemical properties. SSSA. Madison, WI. 